\title{
Intensi Melukai Diri Remaja Ditinjau Berdasarkan Pola Komunikasi Orang Tua
}

\author{
Ridha Afrianti ${ }^{(1)}$ \\ ${ }^{(1)}$ Fakultas Psikologi, Universitas Muhammadiyah Malang, Malang, Indonesia \\ Adolescents' tendency of self-harming continues to increase both quantitatively and \\ qualitatively. Self-harming denotes one of the self-defence strategies to reduce psychological \\ pain, in an attempt of individuals to regain homeostatic emotion. One factor that causes self- \\ harming is the lack of effective communication between adolescents and their parents. Parents \\ themselves oftentimes use various communication patterns, be they consensual, pluralistic, \\ protective, or laissez-faire. The purpose of this study was to examine the impact of such \\ differences in parental communication patterns on self-harming intentions among adolescents. \\ Participants were 103 adolescents drew from an accidental sampling technique. The results \\ showed that parental communication patterns significantly affected adolescents' self-harming \\ intensions.
}

Keywords: adolescents, parental communication patterns, self-harming intentions

Kecenderungan remaja melukai diri terus meningkat baik secara kuantitatif maupun kualitatif. Perilaku melukai diri merupakan salah satu bentuk strategi perlindungan diri untuk membantu mengurangi rasa sakit psikologis, sebagai upaya individu untuk mendapatkan kembali keseimbangan emosional. Salah satu faktor yang menyebabkan perilaku melukai diri adalah kurang efektifnya komunikasi antara remaja dan orang tua mereka. Orang tua biasanya menerapkan pola komunikasi yang berbeda-beda, mulai dari pola komunikasi yang bersifat konsensual, pluralistik, protektif ataupun laissez-faire. Tujuan penelitian ini adalah untuk menguji pengaruh pola komunikasi orang tua yang berbeda-beda tersebut terhadap intensi melukai diri pada remaja. Partisipan adalah 103 remaja yang diperoleh atas dasar sampling aksidental. Hasil penelitian menunjukkan bahwa perbedaan pola komunikasi orang tua berpengaruh secara signifikan terhadap intensi melukai diri pada remaja.

Kata kunci: intensi melukai diri, pola komunikasi orang tua, remaja

MEDIAPSI, 2020, Vol. 6(1), 37-47, DOI: https://doi.org/10.21776/ub.mps.2020.006.01.5

Received: 06-08-2019. Revised: 31-08-2019. Accepted: 07-04-2020. Published online: 12-06-2020

Handling Editor: Intan Rahmawati, Universitas Brawijaya, Malang, Indonesia

*Corresponding author: Ridha Afrianti, Fakultas Psikologi, Universitas Muhammadiyah Malang, Malang, Indonesia. E-mail: aprilrydha@gmail.com

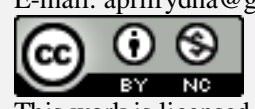

This work is licensed under a Creative Commons Attribution-NonCommercial 4.0 International License.

How to cite this article in accordance with the American Psychological Association (APA) $6^{\text {th }}$ guidelines: Afrianti, R. (2020). Intensi melukai diri remaja ditinjau berdasarkan pola komunikasi orang tua. MEDIAPSI, 6(1), $37-47$. https://doi.org/10.21776/ub.mps.2020.006.01.5

\section{Pendahuluan}

Era globalisasi yang terus berkembang dan semakin modern berdampak pada semakin merosotnya perkembangan sosial dan emosional remaja di Indonesia. Remaja merupakan populasi berjumlah besar dari penduduk dunia. Jumlah remaja dalam rentang usia 10-24 tahun di Indonesia pada tahun 2007 adalah sebesar 64 juta atau $28.64 \%$ dari jumlah penduduk Indonesia (Muadz, Siti, Endang, \& Laurike, 2008).

Remaja semakin sulit mencari dan menemukan cara penyelesaian masalah, yang mengarahkan mereka pada tindakan-tindakan yang mengkhawatirkan. Hal ini bisa dibuktikan berdasarkan sebuah berita di SMP Negeri 
Surabaya. Di sekolah tersebut, seorang guru melaporkan kepada pihak kepolisian bahwa 56 muridnya memiliki luka sayatan yang sama di pergelangan tangan mereka dan setelah diselidiki, ditemukan bahwa mereka melakukan hal tersebut karena memiliki masalah psikologis ataupun depresi (Chozanah, 2018).

Berita lain melaporkan tragedi serupa khsusnya di SMP 18 Pekanbaru. Di sekolah tersebut, sekitar 55 siswa telah ditemukan memiliki luka gores di pergelangan tangan, yang sebagian besar adalah siswa perempuan dan hanya satu siswa laki-laki (Hardiansyah, 2018). Para siswa tersebut diduga melakukan tindakan menyayat tangan sebagai pelampiasan masalah yang terjadi dalam kehidupan mereka. Menurut pengakuan siswa kelas VIII Pekanbaru, ia melakukan perilaku tersebut karena memiliki masalah dengan keluarganya. Siswa lain berinisial $\mathrm{N}$ mengaku bahwa ia sudah melakukan sayat tangan sebanyak dua kali dan dirinya merasa sedikit lega. Hal yang sama diungkapkan siswa berinisial IN yang juga mengakui telah melakukan sayat tangan sebanyak dua kali karena marah kepada teman kelas yang menyembunyikan bukunya hingga ia mendapat hukuman dari sang guru (Tanjung, 2018).

Maraknya kasus menyayat tangan pada remaja tersebut merupakan wujud perilaku melukai diri. Perilaku melukai diri didefinisikan sebagai salah satu bentuk strategi perlindungan diri untuk membantu mengurangi rasa sakit psikologis yang dirasakan individu atau mendapatkan kembali keseimbangan emosional (Buresova, Bartosova, \& Čerňák, 2015). Berdasarkan penelitian sebelumnya, bentuk perilaku melukai diri pada remaja yang berhubungan dengan upaya bunuh diri adalah mengiris atau menyayat kulit (Nock, Joiner, Gordon, Lloyd-Richardson, \& Prinstein, 2006).

Remaja memang telah ditemukan cukup rentan untuk melakukan perilaku melukai diri, sebagaimana telah dibuktikan melalui sebuah penelitian di Australia. Penelitian ini menemukan adanya prevalensi perilaku melukai diri yang berkisar antara 5\% sampai dengan 9\% di kalangan remaja (Swannell, Martin, Scott, Gibbons \& Gifford, 2008). Plante (2007) juga menemukan bahwa remaja yang melakukan tindakan melukai diri di Amerika Serikat setiap tahunnya berjumlah sekitar dua juta, yang 1000 hingga 100.000 diantaranya mengaku pernah menyayat diri. Di Indonesia, belum ada survei yang ditujukan untuk mengungkap prevalensi tindakan melukai diri di kalangan remaja. Meskipun demikian, hasil survei Kekerasan Terhadap Anak Indonesia oleh Kurniasari dkk. (2013) melaporkan data yang cukup menarik. Data tersebut menunjukkan bahwa $13 \%$ remaja berusia 13 sampai 17 tahun melukai diri sebagai reaksi atas kekerasan fisik yang mereka alami. Sementara itu, 6.06\% remaja berusia 18 - 24 tahun melukai diri sebagai dampak kekerasan fisik dan emosional. Temuan ini tentu sangat memprihatinkan karena kebanyakan pelaku melukai diri ini adalah remaja. Padahal, remaja merupakan generasi penerus bangsa. Memang harus diakui bahwa secara umum, masa remaja adalah masa yang penuh permasalahan karena masa tersebut adalah masa transisi dari kanakkanak menuju dewasa. Perkembangan emosionalitas remaja mengalami eskalasi. Terutama pada masa remaja awal, emosi individu bersifat sangat sensitif.

Lingkungan yang kurang kondusif akan menghambat kematangan emosional remaja sehingga mengakibatkan tingkah laku-tingkah laku negatif, misalnya melarikan diri dari kenyataan dan perilaku agresif (Yulianto \& Faturochman, 2016). Argumentasi ini terbukti melalui sebuah penelitian pada 74 remaja berusia 13 sampai 18 tahun yang berasal dari keluarga berpenghasilan tinggi di Belanda. Sebanyak $40 \%$ dari remaja tersebut beresiko tinggi untuk melakukan perilaku eksternalisasi dalam bentuk perilaku agresif (Prawira, 2015). Penelitian lain di Indonesia pada 60 subjek di SMAN 11 Bekasi juga telah membuktikan bahwa kematangan emosi berpengaruh signifikan terhadap kecendrungan self-injury 
(Rizqi-T, 2011). Remaja awal rentan melakukan tindakan melukai diri karena mereka cenderung sulit mengontrol dan mengatur emosinya yang tidak stabil dan sulit meregulasi emosi. Rasa kesepian dan disregulasi emosi pada remaja juga ditemukan berhubungan dengan gangguan melukai diri sendiri tanpa ada niatan bunuh diri dan dengan borderline personality disorder (BPD) (Glenn \& Klonsky, 2013).

Adapun dimensi-dimensi lain yang melatarbelakangi perilaku melukai diri terdiri dari: 1) dimensi lingkungan yang meliputi kehilangan suatu hubungan, konflik interpersonal, tekanan, stress, kurangnya dukungan sosial, 2) dimensi biologis yang meliputi kelainan otak yang membuat individu mencari kepuasan dengan perilaku melukai diri, 3) dimensi kognitif yang meliputi pemikiranpemikiran yang secara otomatis menjadi pencetus perilaku melukai diri dan kognisi yang berhubungan dengan trauma yang pernah dialami, 4) dimensi perilaku, yaitu perilaku yang membuat seseorang menjadi malu secara berlebihan dan merasa layak mendapat hukuman dengan melukai diri sendiri, 5) dimensi afektif yang meliputi kecemasan, tekanan, kepanikan, kemarahan, depresi, rasa malu, dan kebencian (Walsh, 2006).

Penelitian Martin, Swannell, Harrison, Hazell, dan Taylor (2010) mengungkapkan bahwa di Australia, 20\% dari populasi berusia 18 - 24 tahun mengaku pernah melukai diri sendiri setidaknya sekali dalam hidupnya. Penelitian lain mengungkapkan bahwa pada kenyataannya, 1 dari 6 remaja telah mencoba untuk melukai diri sendiri setidaknya sekali dalam kehidupannya (Muehlenkamp, Claes, Havertape, \& Plener, 2012). Sementara itu, Rizqy-T (2011) melakukan penelitian di SMAN 11 Bekasi dan menemukan bahwa $21.7 \%$ siswa memiliki kecendrungan perilaku melukai diri yang tinggi dan $48.3 \%$ siswa memiliki kecendrungan perilaku melukai diri yang sedang. Hasil penelitian lain juga mengungkapkan $0.6 \%$ dari 316 siswa SMKN 3
Balikpapan memiliki keinginan melukai diri yang tinggi (Muthia \& Hidayati, 2015). Hal ini mengindikasikan bahwa remaja Indonesia memiliki kecendrungan dan keinginan untuk melukai diri sendiri sehingga perlu dilakukan asesmen lebih lanjut pada fenomena remaja ini. Niat melakukan perilaku tertentu dalam konsep psikologi sosial disebut intensi sebagai bagian dari sikap manusia yang melatarbelakangi kecenderungan individu melakukan perilaku tertentu (Dayakisni \& Hudaniah, 2009).

Menurut Baron dan Byrne (2005), perilaku individu dapat diketahui melalui intensinya. Semakin besar intensi seseorang untuk melukai diri maka semakin besar juga peluang untuk melakukan tindakan tersebut. Penelitian yang dilakukan oleh Lewis, Rosenrot, dan Santor (2011) menunjukkan bahwa besarnya intensi perilaku secara empiris berhubungan dengan tingginya intensi melukai diri sendiri. Salah satu penyebab perilaku melukai diri adalah kurangnya individu pada masa kanak-kanak dalam mengekspresikan emosi serta kurangnya komunikasi dalam keluarga (Martinson, 1999). Hal ini dibuktikan oleh Wedig dan Nock (2007) dalam penelitiannya yang melaporkan adanya hubungan signifikan antara kritik orang tua yang kurang membangun dan keterlibatan emosional yang berlebihan dengan pikiran dan perilaku melukai diri. Dengan kata lain, kritik orang tua yang kurang membangun serta emosional yang berlebihan akan memengaruhi pikiran anak dan perilaku mereka untuk melukai diri.

Berdasarkan hasil kajian literatur oleh Wibisono (2016), perilaku melukai diri muncul dari dua faktor, yaitu faktor internal dan faktor eksternal. Faktor internal meliputi karakteristik neurosis ataupun psikotis, sifat bawaan dari kecerdasan emosional dan emosi-emosi negatif. Faktor eksternal meliputi trauma yang disebabkan karena lingkungan sekolah yang kurang memadai dan pola asuh dalam keluarga. Hal ini sesuai dengan hasil studi di Amerika Serikat tentang karakteristik dan prediktor self 
mutilation pada 256 narapidana yang melakukan perilaku melukai diri. Penelitian ini mengungkap bahwa pengalaman masa kecil dalam konteks keluarga dan dalam konteks pengasuhan sangat berhubungan dengan perilaku melukai diri (Roe-Sepowitz, 2007).

Peran keluarga memang sangat penting untuk perkembangan anak. Hubungan orang tua dan anak yang salah sering menjadi salah satu penyebab kegagalan remaja. Kegagalan remaja dalam penyesuaian diri terhadap perubahanperubahan yang terjadi pada perkembangannya akan menimbulkan kurangnya kepercayaan diri, perasaan dikucilkan dari lingkungan sekitar, kecenderungan melakukan perilaku menyimpang, dan, yang lebih ekstrim lagi, depresi, kecemasan, serta melukai diri sendiri. Komunikasi orang tua dan anak adalah suatu proses hubungan yang baik antara anak dengan orang tua, dimana orang tua mampu memberi rasa aman bagi anak melalui komunikasi yang baik dan tepat. Hal ini selanjutnya bisa membangun keterbukaan dan kepercayaan diri dalam menghadapi dan memecahkan masalah (Gunarsa, 2004). Komunikasi orang tua dan anak biasanya disebut dengan pola komunikasi dalam keluarga. Pola komunikasi dalam keluarga dapat dipahami sebagai pola hubungan antara orang tua dengan anak yang saling membagi perhatian satu sama lain. Mcleod dan Chaffle (dalam Hiasinta, 2016) menjelaskan bahwa pola komunikasi keluarga merupakan pola orang tua dalam mengembangkan gaya berkomunikasi dengan anaknya. Definisi ini diterapkan dalam penelitian Erdner (2015) yang menggunakan teori dan alat ukur pola komunikasi keluarga untuk menilai komunikasi orang tua pada anak dalam penelitiannya.

Pola komunikasi orang tua sangat bervariasi. Sebagian orang tua menerapkan pola komunikasi yang penuh percakapan sehingga ada keterbukaan pada anak dan penuh kasih sayang. Sebagian orang tua yang lain menerapkan komunikasi yang menekankan kepatuhan dengan aturan-aturan yang strict dalam keluarga. Perbedaan pola komunikasi inilah yang dapat berpengaruh terhadap perbedaan perkembangan sosio-emosional remaja sehingga akan muncul perilaku menyimpang, yang salah satunya adalah perilaku melukai diri. Menurut Koener dan Fitzpatrick (2002), ada empat kategori pola komunikasi dalam keluarga. Pertama adalah pola konsensual, yang mendorong anak terbuka kepada orang tua mereka dan memiliki kemampuan untuk mengontrol diri dengan baik, mampu menghindari konflik, serta memiliki relasi yang baik dengan lingkungan sekitarnya (Koerner \& Fitzpatrick, 2002). Keluarga yang menerapkan komunikasi konsensual memfasilitasi remaja untuk memiliki intensi melukai diri yang rendah. Alasannya, salah satu faktor melukai diri sendiri adalah kurangnya peran model masa kecil dalam mengekspresikan emosi serta kurangnya komunikasi antar anggota keluarga (Martinson, 1999).

Pola komunikasi kedua adalah pola pluralistik. Dengan pola komunikasi ini, anak terlatih untuk berpikir bebas dan mampu menjaga relasi, didorong untuk berkomunikasi dan bertukar ide secara terbuka serta untuk menikmati berbagai macam nilai. Dengan ciriciri seperti ini, pola komunikasi pluralistik membentuk remaja untuk lebih terbuka dan mampu menciptakan hubungan yang harmonis (Koerner \& Fitzpatrick, 2002).

Menurut hasil penelitian Setyorini (2018), keluarga yang harmonis berhubungan dengan rendahnya kenakalan remaja. Salah satu bentuk kenakalan remaja adalah perilaku melukai diri sendiri dan melukai orang lain (Hurlock, 1999). Pola komunikasi ketiga disebut dengan pola protektif. Pada tipe komunikasi ini, orang tua sangat jarang bahkan tidak pernah meluangkan waktunya untuk berdiskusi dengan sang anak. Hal ini memungkinkan remaja akan memiliki intensi melukai diri yang tinggi karena pada tipe keluarga ini orang tua sangat menekankan pada kepatuhan dan komunikasi yang tertutup. Polk dan Liss (2009) menemukan bahwa kasih 
sayang emosional dan pola asuh orang tua yang menekankan aturan aturan yang strict akan memicu munculnya perilaku melukai diri.

Laissez-faire adalah pola komunikasi yang terakhir. Keluarga yang menerapkan pola komunikasi ini ditandai dengan kurangnya interaksi antara anggota keluarga. Orang tua tipe ini hanya memiliki sedikit minat dalam kehidupan anak. Lieberman (2004) mengatakan bahwa pelaku melukai diri cenderung mengalami pengabaian dan penolakan dari orang tua mereka di masa kecil dan tidak mendapatkan perhatian penuh dari orang tua yang mengalami perceraian.

Berbeda dengan penelitian-penelitian sebelumnya yang memfokuskan pada faktor internal, penelitian ini menguji perbedaan pola komunikasi orang tua sebagai faktor eksternal terhadap intensi melukai diri pada remaja. Berdasarkan rangkaian penjelasan di atas, penelitian ini bertujuan untuk mengetahui perbedaan intensi melukai diri pada remaja ditinjau berdasarkan pola komunikasi orang tua. Hipotesa yang diajukan adalah terdapat perbedaan tingkat intensi melukai diri pada remaja ditinjau berdasarkan pola komunikasi orang tua.

\section{Metode}

\section{Partisipan dan desain penelitian}

Subjek penelitian adalah 103 remaja awal yang berusia antara 12 tahun sampai dengan 15 tahun (laki-laki $=45$, perempuan $=$ 58), yang direkrut atas dasar accidental sampling. Dengan teknik sampling ini, peneliti memberikan instrumen penelitian kepada subjek penelitian sesuai dengan kriteria yang ditetapkan dan bersedia berpartisipasi.

Penelitian ini menggunakan pendekatan kuantitatif komparatif non-eksperimen. Dengan desain ini, variabel independen tidak dimanipulasi melalui suatu eksperimen tetapi diukur dengan suatu skala dan selanjutnya dibuat kategorisasi atas dasar skor skala tersebut (Sugiyono, 2015). Secara lebih spesifik, variabel independen (X) dalam penelitian ini adalah perbedaan pola komunikasi orang tua sementara variabel dependen (Y) adalah intensi melukai diri.

\section{Prosedur dan instrumen penelitian}

Penelitian dilaksanakan melalui tiga prosedur, yaitu persiapan penelitian, pelaksanaan penelitian, dan analisis data. Dalam tahap persiapan, peneliti melakukan studi kepustakaan dari berbagai sumber, seperti jurnal, penelitian terdahulu, buku serta media elektronik terkait dengan fenomena yang diteliti. Selanjutnya peneliti menentukan desain dan metode penelitian yang tepat sesuai dengan topik penelitian dan kemudian dilanjutkan dengan menyusun alat ukur penelitian berlandaskan pada aspek dan dimensi dari konsep teori penelitian, yaitu teori intensi melukai diri dan teori pola komunikasi orang tua.

Pada tahap kedua atau pelaksanaan penelitian, peneliti melakukan uji coba (try out) dimana alat ukur disebarkan kepada 50 siswa SMP Muhammadiyah 06 Dau pada tanggal 19 Maret 2019. Langkah berikutnya adalah melakukan pengumpulan data dengan cara membagikan skala intensi melukai diri dan skala pola komunikasi orang tua melalui google formulir kepada subjek penelitian yang telah ditentukan peneliti yaitu remaja pada tanggal 27 Maret 2019 hingga 3 April 2019. Prosedur ketiga adalah menganalisis data menggunakan SPSS for Wndows versi 22.0. Teknik statistik yang digunakan adalah one-way betweensubjects untuk menguji peran jenis-jenis pola komunikasi orang tua terhadap intensi melukai diri.

Dalam penelitian ini, pola komunikasi orang tua sebagai variabel independen (Y) diukur menggunakan adaptasi skala Revised Family Communication Pattern yang dikembangkan oleh Fitzpatrick dan Ritchie (1994). Skala tersebut terdiri dari 16 aitem dengan nilai reliabilitas $(\alpha)$ sebesar 0.899 . Skala ini terdiri dari dua dimensi, yaitu dimensi orientasi percakapan (12 aitem) dan dimensi 
kepatuhan (4 aitem). Pengukuran skala ini akan menghasilkan empat pola komunikasi. Kombinasi dari tingginya orientasi percakapan dan kepatuhan dikategorisasikan sebagai pola komunikasi konsensual. Kombinasi tingginya orientasi percakapan dan rendahnya kepatuhan dikategorisasikan sebagai pola komunikasi pluralistik. Kombinsi rendahnya orientasi percakapan dan tingginya kepatuhan dikategorisasikan sebagai pola komunikasi protektif. Kombinasi rendahnya orientasi percakapan dan rendahnya kepatuhan dikategorisasikan sebagai pola komunikasi laizes-faire.

Intensi melukai diri sebagai variabel dependen (Y) diukur atas dasar aspek-aspek pembentuk intensi oleh Fishbein dan Ajzen (dalam Dayakisni \& Hudaniah, 2009), yaitu sikap, norma-norma subjektif, dan perceived behavioral control. Aspek-aspek ini selanjutnya dikaitkan dengan bentuk-bentuk melukai diri menurut Briere dan Gil (1998), yang terdiri dari menyayat kulit, membenturkan atau memukul diri, dan membakar bagian tubuh. Instrumen penelitian skala intensi melukai diri dikembangkan oleh peneliti sebanyak 33 item dengan reliabilitas $(\alpha)$ sebesar 0.869 .

Kedua alat ukur pada penelitian ini menggunakan skala Likert yang terdiri dari aitem yang mendukung konsep (favorable) dan aitem yang tidak mendukung konsep (unfavorable). Rentang skor untuk masing aitem adalah 1 (Sangat Tidak Setuju) sampai dengan 5 (Sangat Setuju).

\section{Hasil}

Tabel 1 di bawah ini menampilkan hasil analisis untuk menguji hipotesis penelitian.

Tabel 1. Hasil Uji Anova Peran Simultan Jenis-Jenis Pola Komunikasi Orang Tua terhadap Intensi Melukai Diri

\begin{tabular}{lcccc}
\hline & \multicolumn{3}{c}{ Mean } & Sig. \\
\hline Between Groups & 3 & Square & $F$ & 0.001 \\
Within Groups & 99 & 802,009 & 6.224 & \\
Total & 102 & & & \\
\hline
\end{tabular}

Berdasarkan Tabel 1 di atas, dapat disimpulkan bahwa jenis-jenis pola komunikasi orang tua berperan signifikan dalam menjelaskan tingkat intensi melukai diri pada remaja. Dengan hasil ini, hipotesis dalam penelitian bisa diterima. Secara lebih spesifik, Tabel 2 menunjukkan bahwa intensi melukai diri lebih tinggi secara signifikan pada pola komunikasi protektif dibandingkan dengan pola komunikasi konsensual dan pluralistik.

Tabel 2. Peran Parsial Pola Komunikasi Orang Tua Konsensual, Pluralisttik, Protektif dan Laissez-Faire terhadap Intensi Melukai Diri

\begin{tabular}{|c|c|c|c|c|c|c|}
\hline \multirow[t]{2}{*}{$\begin{array}{l}\text { Jumlah } \\
\text { Subjek }\end{array}$} & \multicolumn{2}{|c|}{$\begin{array}{c}\text { Kategori } \\
\text { intensi } \\
\text { melukai diri }\end{array}$} & \multirow{2}{*}{$\begin{array}{c}\text { Pola } \\
\text { komunikasi }\end{array}$} & \multirow{2}{*}{$\begin{array}{l}\text { Perbandingan } \\
\text { pola } \\
\text { komunikasi }\end{array}$} & \multirow{2}{*}{$\begin{array}{c}\text { Mean } \\
\text { dfference }\end{array}$} & \multirow[t]{2}{*}{ Sig. } \\
\hline & Tinggi & Rendah & & & & \\
\hline \multirow{3}{*}{5} & 0 & 5 & & Pluralistik & 4,267 & 0.915 \\
\hline & & $100 \%$ & Konsensual & Protektif & $-16.218^{*}$ & 0.006 \\
\hline & & & & Laissez-faire & -9.019 & 0.136 \\
\hline \multirow{3}{*}{3} & 0 & 3 & & Konsensual & -4.267 & 0.915 \\
\hline & & $100 \%$ & Pluralistik & Protektif & $-20.485^{*}$ & 0.004 \\
\hline & & & & Laissez-faire & -13.286 & 0.063 \\
\hline \multirow{3}{*}{11} & 4 & 7 & & Konsensual & $16.218^{*}$ & 0.006 \\
\hline & 36.4 & $63.6 \%$ & Protektif & Pluralistik & $20.485^{*}$ & 0.004 \\
\hline & & & & Laissez-faire & 7.199 & 0.066 \\
\hline \multirow{3}{*}{84} & 8 & 76 & & Konsensual & 9.019 & 0.136 \\
\hline & $9.5 \%$ & $90.5 \%$ & Laissez-faire & Pluralistik & 13.286 & 0.063 \\
\hline & & & & Protektif & -7.199 & 0.066 \\
\hline \multirow{2}{*}{ Total } & 12 & 91 & & & & \\
\hline & $11.7 \%$ & $88.3 \%$ & & & & \\
\hline
\end{tabular}

\section{Diskusi}

Penelitian ini bertujuan untuk menguji sejauhmana perbedaan pola komunikasi orang tua (konsensual, pluralistik, protektif, laissezfaire) berperan signifikan dalam menjelaskan tingkat intensi melukai diri pada remaja berusia 12-15 tahun. Mendukung hipotesis yang diajukan, hasil penelitian menunjukkan adanya perbedaan yang signifikan intensi melukai diri berdasarkan jenis-jenis pola komunikasi orang tua.

Temuan tersebut sesuai dengan hasil kajian literatur oleh Wibisono (2016) yang menyimpulkan bahwa perilaku melukai diri muncul dari dua faktor, yaitu faktor internal dan faktor eksternal. Faktor internal meliputi 
karakteristik neurosis ataupun psikotis, sifat bawaan dari kecerdasan emosional dan emosiemosi negatif. Faktor eksternal berkaitan dengan trauma yang disebabkan karena lingkungan sekolah yang kurang memadai dan pola asuh dalam keluarga.

Pola komunikasi yang diterapkan setiap orang tua tentunya bervariasi. Sebagian orang tua sering menghabiskan waktunya untuk bercakap-cakap dengan anaknya dan memberikan perhatian yang tepat pada anak. Sebagian orang tua lain justru sebaliknya, hanya memiliki sedikit minat pada kehidupan anak bahkan jarang berinteraksi dengan anak. Kedua hal tersebut tentunya akan memiliki dampak yang berbeda pula pada anak. Pola komunikasi yang protektif akan berdampak buruk pada anak karena tipe pola komunikasi ini cenderung membuat anak menjadi lebih agresif. Percakapan yang kurang serta banyaknya aturan-aturan orang tua yang diterapkan pada anak akan memicu anak untuk melukai diri sendiri. Argumentasi ini diperkuat oleh penelitian Polk dan Liss (2009), yang menyebutkan bahwa orang tua yang mengasuh anak penuh dengan aturan-aturan yang ketat akan memicu munculnya perilaku melukai diri. Penelitian lain juga menyebutkan bahwa perilaku melukai diri disebabkan oleh kurangnya mekanisme coping yang baik dalam keluarga (Walsh, 2006). Mendukung argumentasi ini, penelitian ini menemukan bahwa prevalensi intensi melukai diri pada remaja dengan pola komunikasi orang tua yang protektif adalah 36.4\% (4 orang dari 103 subjek).

Penelitian ini juga menemukan bahwa intensi melukai diri pada remaja dengan pola komunikasi protektif tidak berbeda secara signifikan dengan intensi melukai diri pada remaja dengan pola komunikasi laissez-faire. Hal ini disebabkan karena pada dua tipe pola komunikasi tersebut, orang tua tidak banyak berinteraksi dan melakukan percakapan dengan anak. Temuan ini sejalan dengan hasil penelitian sebelumnya (Tulloch, Blizzard \&
Pinkus, 1997), yang melaporkan bahwa kurangnya komunikasi antara remaja dan orang tua menjadi pemicu munculnya perilaku melukai diri pada remaja.

Penelitian ini melaporkan bahwa hanya 8 dari 84 subjek pada tipe pola komunikasi laissez-faire dan 4 dari 11 subjek pada tipe pola komunikasi protektif memiliki intensi melukai diri yang tinggi. Hal ini mungkin disebabkan karena adanya keterbatasan dalam penelitian ini. Keterbatasan tersebut bersumber pada penggunaan tiga bentuk melukai diri dalam penelitian ini, yang mengacu pada Briere dan Gill (1998): menyayat tangan, memukul diri, dan membakar salah satu bagian tubuh. Ada kemungkinan bahwa tiga bentuk tindakan melukai diri tersebut tidak sepenuhnya mewakili perilaku melukai diri pada subjek dalam penelitian ini. Sementara itu, Greydanus dan Shek (2009) menyebutkan bentuk-bentuk lain perilaku melukai diri, yang mencakup mengonsumsi obat-obatan, meracuni diri sendiri, mengiris kulit, membakar bagian tubuh, mencakar bagian tubuh, mencubit tubuh sendiri, memukuli diri sendiri, menembak bagian tubuh, menggantung diri, terjun bebas dari tempat tinggi, dan terjun ke dalam sumur.

Selain itu, religiusitas juga dapat menjadi salah satu faktor penyebab lain. Kuatnya nilai religiusitas yang terdapat pada budaya Asia juga akan memengaruhi bagaimana seseorang menjalani kehidupannya. Ada sebuah pernyataan umum yang menjadi kepercayaan budaya Asia bahwa "kita tidak boleh berbuat apapun yang melanggar agama kita". Individu yang sangat kuat memegang nilai-nilai agama mungkin memiliki intensi melukai diri yang rendah karena adanya larangan dalam agama untuk melakukan hal tersebut. Faktor lain yang juga berpotensi memengaruhi adalah adanya perbedaan pola komunikasi orang tua antara budaya individualisme dan kolektivisme.

Temuan lain dalam penelitian ini menunjukkan tidak adanya perbedaan signifikan perilaku melukai diri pada remaja 
dengan pola komunikasi orang tua konsensual dan pluralistik. Orang tua yang menerapkan dua pola komunikasi ini tidak memberikan kendali yang berlebihan pada anak-anak mereka. Meskipun demikian, orang tua bersedia menerima pendapat anak dan membiarkan mereka berpartisipasi dalam pengambilan keputusan keluarga (Koerner \& Fitzpatrick, 2002). Hal ini tentunya memfasilitasi anak untuk mampu bertukar ide dan menikmati berbagai macam nilai kehidupan, yang mendorong remaja untuk bersikap terbuka dan mampu menciptakan hubungan yang harmonis (Paramita, 2015). Sebagaimana ditemukan dalam penelitian Juby dan Farrington (2001), keluarga yang harmonis berperan signifikan dalam menekan tingkat kenakalan remaja, dan salah satu bentuk kenakalan remaja adalah perilaku melukai diri sendiri dan melukai orang lain (Hurlock, 1999).

Temuan terakhir, penelitian ini menunjukkan bahwa 12 subjek dari 103 responden berusia 12-15 tahun memiliki intensi melukai diri yang tinggi. Hasil penelitian ini sesuai dengan hasil penelitian sebelumnya (Muthia \& Hidayati, 2015) yang juga menemukan bahwa sebanyak $0.6 \%$ remaja Indonesia memiliki keinginan melukai diri yang tinggi. Mullis dan Chapman (2000) menjelaskan bahwa remaja cenderung menggunakan emotion focus coping dalam menghadapi dan menyelesaikan masalah. Emotion focus coping adalah penyelesaian masalah dengan cara memperkecil tekanan yang dirasakan untuk meraih rasa nyaman. Dengan demikian, emotion focus coping juga biasa disebut sebagai usaha untuk mengurangi atau mengatasi keadaan emosi yang disebabkan oleh situasi stres. Bentuk respon emosional yang dilakukan melalui perilaku seperti itu adalah, sebagai contoh, mengonsumsi alkohol, merokok, mencari dukungan emosional yang salah, serta melakukan berbagai aktivitas yang bertujuan untuk mengalihkan perhatian atau konsentrasi psikologis dari permasalahan sebenarnya.
Sebagaimana dipaparkan di atas, penelitian ini memiliki sejumlah kekurangan. Pertama, penelitian ini tidak mengukur tingkat religiusitas pada subjek penelitian, yang terbukti berpengaruh terhadap pikiran dan perilaku melukai diri pada remaja (Amit dkk., 2014). Kedua, penelitian ini mengoperasionalisasikan perilaku melukai diri hanya dalam bentuk tiga perilaku (menyayat tangan, memukul diri, dan membakar salah satu bagian tubuh), sementara Greydanus dan Shek (2009) mengoperasionalisasikan perilaku tersebut secara lebih komprehensif. Penelitian lanjutan dengan demikian bisa mengukur religiusitas dan bentuk-bentuk perilaku melukai diri yang lebih komprehensif untuk mendapatkan gambaran yang lebih jelas terkait dengan sejauh mana jenis-jenis pola komunikasi orang tua berdampak pada perilaku melukai diri pada remaja.

\section{Daftar Pustaka}

Amit, B. H., Krivoy, A., Mansbach-Kleinfeld, I., Zalsman, G., Ponizovsky, A. M., Hoshen, M., ... \& Shoval, G. (2014). Religiosity is a protective factor against self-injurious thoughts and behaviors in Jewish adolescents: Findings from a nationally representative survey. European Psychiatry, 29(8), 509-513.

https://doi.org/10.1016/j.eurpsy.2014.04 .005

Baron, R.A., \& Byrne (2005). Psikologi sosial (jilid 2, edisi kesepuluh). Jakarta: Erlangga.

Briere, J., \& Gil, E. (1998). Self-mutilation in clinical and general population samples: Prevalence, correlates, and functions. American Journal of Orthopsychiatry, 68(4), 609-620. https://doi.org/10.1037/h0080369

Burešová, I., Bartošová, K., \& Čerňák, M. (2015). Connection between parenting styles and self-harm in adolescence. Procedia Social and 
Behavioral Sciences, 171, 1106-1113. https://doi.org/10.1016/j.sbspro.2015.01. 272

Chozanah, R. (2018, September 10). Ada 56 siswa SMP di Surabaya lukai diri sendiri ternyata ada faktor pendorongnya. Nakita.grid.id. Diakses dari https://nakita.grid.id/read/02934880/ada -56-siswa-smp-di-surabaya-lukai-dirisendiri-ternyata-ada-faktorpendorongnya?page $=$ all

Dayakisni, T., \& Hudaniah. (2009). Psikologi sosial (cetakan keempat). Malang: UMM Press.

Erdner (2015). The Relationship between parent communication orientations and the self-efficacy of student-athletes (Thesis, The University of Tennessee, Knoxville, United States of America). Diunduh dari https://trace.tennessee.edu/cgi/viewcont ent.cgi?referer=https://www.google.com $/ \&$ httpsredir $=1 \&$ article $=4761 \&$ context $=$ utk_gradthes

Fitzpatrick, M. A., \& Ritchie, L. D. (1994). Communication schemata within the family: Multiple perspectives on family interaction. Human Communication Research, 20(3), 275301. https://doi.org/10.1111/j.1468-

2958.1994.tb00324.x

Glenn, C. R., \& Klonsky, D. (2013). Nonsuicidal self-injury disorder: An empirical investigation in adolescent psychiatric patients. Journal of Clinical Child \& Adolescent Psychology, 42(4), 496-507. https://doi.org/10.1080/15374416.2013. 794699

Greydanus, D. E., \& Shek, D. (2009). Deliberate self-harm and suicide in adolescents. The Keio Journal of Medicine, 58(3), 144-151. https://doi.org/10.2302/kjm.58.144
Gunarsa, S.D. (2004). Psikologi praktis anak, remaja dan keluarga. Jakarta: PT. Gunung Mulia.

Hardiansyah, R. (2018). Sebulan 152 siswa smp sayat tangan para murid mengaku buat penuhi tantangan. Tribunnews.com. Diakses dari https://lampung.tribunnews.com/2018/1 0/05/152-siswa-smp-sayat-tangandalam-sebulan-para-murid-mengakubuat-penuhi-tantangan

Hiasinta, Y. (2016). Pengaruh pola komunikasi orang tua terhadap kepercayaan diri siswa Kelas V SD Tarakanita Bumito Yogyakarta tahun pelajaran 2015-2016 (Skripsi, Universitas Sanata Dharma Yogyakarta, Indonesia). Diunduh dari https://repository.usd.ac.id/8575/

Hurlock, E.B. (1999). Psikologi perkembangan: Suatu pendekatan sepanjang rentang kehidupan (edisi kelima). Jakarta: Erlangga.

Juby, H., \& Farrington, D. P. (2001). Disentangling the link between disrupted families and delinquency: Sociodemography, ethnicity and risk behaviours. British Journal of Criminology, 41(1), 22-40. https://doi.org/10.1093/bjc/41.1.22

Koerner, A.F \& Fitzpatrick, M.A. (2002). Toward a theory of fammily communication. Communication Theory, 12(1), 70-91. https://doi.org/10.1111/j.14682885.2002.tb00260.x

Kurniasari, A., Wismaayanti, Y.F., Irmayani., Husmiati., Widodo, N., \& Susantyo, B. (2013). Survey kekerasan terhadap anak indonesia tahun 2013. Kemsos.go.id. Diakses dari http://puslit.kemsos.go.id/upload/post/fil es/4fb404d806e55b69e7fa7d410634491 4.pdf

Lewis, S.P., Rosenrot, S.A., \& Santor, D.A. (2011). An integrated model of selfharm: Identifying predictors of intent. 
Canadian Journal of Behavioural Science, $\quad 43(1), \quad 20-29$. https://doi.org/10.1037/a0022076

Lieberman, R. (2004, November 7). Understanding and responding to students who self-mutilate. Principal Leadership Magazine, 4, 10-13. Diunduh dari http://www.selfinjury.bctr.cornell.edu/p ublications/b1.pdf

Martin, G., Swannell, S., Harrison, J., Hazell, P., \& Taylor, A. (2010). The Australian national epidemiological study of selfinjury (ANESSI). Australia: Centre for Suicide Prevention Studies. Diakses dari https://www.researchgate.net/publicatio n/320841702_Australian_National_Epid emiological_Study_of_SelfInjury_ANESSI_Final_Report

Martinson, D. (1999). Self injury fact sheet. New York: Amazon.

Muadz, M.M., Siti, F., Endang, A.S., \& Laurike, M. (2008). Keterampilan hidup (life skills) dalam program kesehatan remaja. Jakarta: BKKBN Direktorat Remaja dan Perlindungan Hak-Hak Reproduksi.

Muehlenkamp, J.J., Claes, L. Haverta, L., \& Plener, P.L. (2012). International prevalence of adolescent nonsuicidal self-injury and deliberate self-harm. Child and Adolescent Psychiatry and Mental Health, 6(10). https://doi.org/10.1186/1753-2000-6-10

Mullis, R. L., \& Chapman, P. (2000). Age, gender, and self-esteem differences in adolescent coping styles. The Journal of Social Psychology, 140(4), 539-541. https://doi.org/10.1080/0022454000960 0494

Muthia, E.N., \& Hidayati, D.S. (2015). Kesepian dan keinginan melukai diri sendiri remaja. Jurnal Ilmiah Psikologi, 2(2), 185-198. https://doi.org/10.15575/psy.v2i2.459
Nock, M. K., Joiner Jr, T. E., Gordon, K. H., Lloyd-Richardson, E., \& Prinstein, M. J. (2006). Non-suicidal self-injury among adolescents: Diagnostic correlates and relation to suicide attempts. Psychiatry Research, 144(1), 65-72. https://doi.org/10.1016/j.psychres.2006. 05.010

Paramita, A.A.A.R (2015). Hubungan antara dimensi pola komunikasi keluarga dengan kecendrungan pembelian impulsif (Skripsi, Unversitas Sanata Dharma Yogyakarta, Indonesia). Diunduh dari https://repository.usd.ac.id/4239/2/1091 14025_full.pdf

Plante, L.G. (2007). Bleeding to ease the pain. Westport, CT: Praeger Publishers.

Polk, E., Liss, M. (2009). Exploring the motivation behind self-injury. Counseling Psychology Qouartely, 22(2), 233-241. https://doi.org/10.1080/0951507090321 6911

Prawira, A.E. (2015, Oktober 16). Suasana hati remaja lebih mudah berubah. Liputan6.com. Diakses dari https://www.liputan6.com/health/read/2 341224/suasana-hati-remaja-lebihmudah-berubah

Rizqi-T, M. I. (2011). Pengaruh kematangan emosi terhadap kecendrungan perilaku self injury pada remaja (Skripsi, Universitas Islam Negeri Syarif Hidayahtullah, Jakarta, Indonesia). Diunduh dari http://repository.uinjkt.ac.id/dspace/bitst ream/123456789/4355/1/M.ILMI\%20RI ZQI\%20T-FPS.PDF

Roe-Sepowitz, D. (2007). Characteristics and predictors of self-mutilation: A study of incarcerated women. Criminal Behaviour and Mental Health, 17(5), 312-

321. https://doi.org/10.1002/cbm.665 
Setyorini, A. (2018). Hubungan antara keharmonisan keluarga dengan kenakalan remaja (Skripsi, Universitas Kristen Sayta Wacana Salatiga, Indonesia). Diakses dari httpspository.uksw.edu/bitstream/12345 6789/17791/2/T1_802014163_Full\%20t ext.pdf

Sugiyono. (2015). Metode penelitian kombinasi. Bandung: Alfabeta.

Swannell, S., Martin, G., Scott, J., Gibbons, M., \& Gifford, S. (2008). Motivations for self-injuey in an adolescent inpatient population: Development of a selfreport measure. Australian Psychiatry, 16(2): 98-103. https://doi.org/10.1080/1039856070163 6955

Tanjung, B. H. (2018, Oktober 02). Miris siswa smp mengaku dapat kepuasan setelah menyayat tangan. Sindonews.com. Diakses dari https://daerah.sindonews.com/berita/134 2891/174/miris-siswi-smp-mengakudapat-kepuasaan-setelah-menyayattangan

Tulloch, A.L., Blizzard, L., Pinkus, Z. (1997). Adolscent parent communication in self harm. Journal of Adolescent Health, 21, 267-75. https://doi.org/10.1016/S1054139X(97)00118-3

Walsh, B. W. (2006). Treating self-injury: A practical guide. New York: The Guilford Press.

Wedig, M. M., Nock, M.K. (2007). Parental expressed emotion and adolescent selfinjury. Journal of the American Academy of Child \& Adolescent Psychiatry, 46(9), 1171-1178. https://doi.org/10.1097/chi.0b013e3180c a9aaf

Wibisono, B. K (2016). Kajian literatur tentang pola asuh dan karakteristik kepribadian sebagai faktor penyebab perilaku melukai diri pada remaja. Prosiding Seminar Nasional Psikologi:
Empowering Self. ISBN 978-602-114530-2. Diunduh dari http://digilib.mercubuana.ac.id/manager/ t!@file_artikel_abstrak/Isi_Artikel_979 041186656.pdf

Yulianto, J.E., \& Faturochman. (2016). The Impact of interethnic marital relation on the dynamics of interdependence: A phenomenological finding from javanese and chinese coupls in Indonesia. Makara Hubs-Asia, 20(2), 88-100. DOI: 10.7454/mssh.v20i2.3490 